\title{
Sensitivity of state aid allocation to measures of needs and resources in local governments
}

Adam Dale Baus

West Virginia University

Follow this and additional works at: https://researchrepository.wvu.edu/etd

\section{Recommended Citation}

Baus, Adam Dale, "Sensitivity of state aid allocation to measures of needs and resources in local governments" (2002). Graduate Theses, Dissertations, and Problem Reports. 853.

https://researchrepository.wvu.edu/etd/853

This Thesis is protected by copyright and/or related rights. It has been brought to you by the The Research Repository @ WVU with permission from the rights-holder(s). You are free to use this Thesis in any way that is permitted by the copyright and related rights legislation that applies to your use. For other uses you must obtain permission from the rights-holder(s) directly, unless additional rights are indicated by a Creative Commons license in the record and/ or on the work itself. This Thesis has been accepted for inclusion in WVU Graduate Theses, Dissertations, and Problem Reports collection by an authorized administrator of The Research Repository @ WVU. For more information, please contact researchrepository@mail.wvu.edu. 
SENSITIVITY OF STATE AID ALLOCATION TO MEASURES OF

NEEDS AND RESOURCES IN LOCAL GOVERNMENTS

by

Adam D. Baus

Thesis submitted to the College of Arts and Sciences at West Virginia University in partial fulfillment of the requirements for the degree of Sociology

Master of Arts in Sociology

Approved by

Dr. F. Carson Mencken, Committee Chairperson

Dr. Christopher Plein

Dr. Ronald Althouse

Department of Sociology and Anthropology

School of Applied Social Sciences

Morgantown, West Virginia

2002

Keywords: State aid, Allocation, Local government

Copyright 2002 Adam D. Baus 


\section{Abstract \\ SENSITIVITY OF STATE AID ALLOCATION TO MEASURES \\ OF NEEDS AND RESOURCES IN LOCAL GOVERNMENTS}

\section{by Adam D. Baus}

This analysis examines the sensitivity of state intergovernmental aid, per capita, to measures of resources, infrastructure, social services, social problems and demographics in Northern and Southern local governments in 1982 and 1992. Time-periods chosen are based on the potential for domestic policies born through new federalism to harm local governments through lesser amounts of available state aid. North and South are compared to account for possible regional differences. Regardless of region and time however, redistribution efforts to local governments with higher levels of need and lower levels of resources are not particularly good. Redistribution tendencies present in 1982 declined by 1992 in both the North and South. Southern local governments in 1982 and 1992 did not show more willingness, or ability, to target state aid to areas with high need and low resources. Redistribution efforts being weak in both the North and South contradicts the frostbelt/sunbelt distinction. 


\section{DEDICATION}

The author wishes to dedicate this research to his parents and Angela. 


\section{ACKNOWLEDGMENTS}

Special thanks for the support and guidance of Dr. Carson Mencken, Dr. Christopher Plein and Dr. Ronald Althouse. 


\section{TABLE OF CONTENTS}

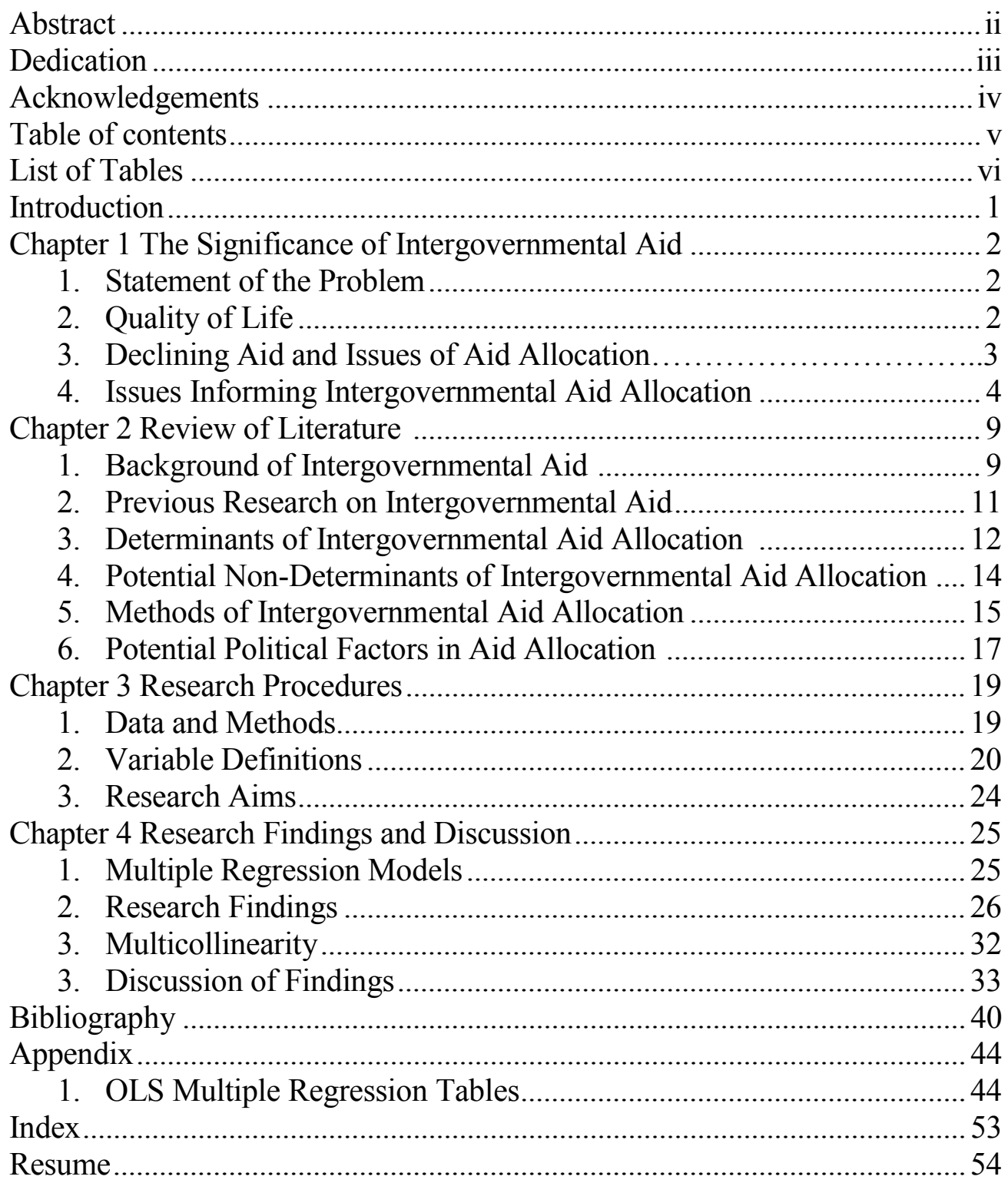




\section{LIST OF TABLES}

Table 1. Means, SD and Total N of Variables for Northern States, 1982 ........44

Table 2. Means, SD and Total N of Variables for Southern States, 1982 ........45

Table 3. Means, SD and Total N of Variables for Northern States, 1992 ..... 46

Table 4. Means, SD and Total N of Variables for Southern States, 1992.... 47

Table 5. OLS Multiple Regression Coefficients for Northern States, 1982 ... 48

Table 6. OLS Multiple Regression Coefficients for Southern States, 1982 .. 49

Table 7. OLS Multiple Regression Coefficients for Northern States, 1992 .. 50

Table 8. OLS Multiple Regression Coefficients for Southern States, 1992 .. 51

Table 9. Composite OLS Multiple Regression Coefficients................ 52 


\section{INTRODUCTION}

The purpose of this research is to examine the sensitivity of state intergovernmental aid to levels of needs and resources within local governments. To what extent are state aid figures, per capita, positively correlated with percent of individuals living in older housing, percent receiving SSI and Social Security, crime rate, percent below poverty and percent unemployed? Conversely, to what extent are state aid figures, per capita, redistributional in character? In other words, to what extent is state aid per capita negatively correlated with property value, total tax per capita and percent with a college degree or more? New federalism highlights possible regional differences, or frostbelt/sunbelt distinctions, in allocation (Cole and Delbert 1983). This study therefore examines the potential for both time-period and regional differences in sensitivity to needs and resources by comparing per capita state intergovernmental aid in 1982 and 1992 within Northern and Southern states. The year 1982 pre-dates many changes in domestic policy, while 1992 is after the fact.

This analysis is not intended to argue that per capita intergovernmental aid from states should be positively related with every measure of need, or that state aid per capita should be negatively associated with all measures of resources. In other words, taking into account the numerous programs and services funded through state intergovernmental aid, it is not expected that state aid per capita will be consistently redistributed to local governments with greater signs of socioeconomic hardship. The review of literature demonstrates that this is not the case. Instead, this analysis is intended to examine the relationship of state aid per capita to measures of resources, infrastructure, social services, social problems and demographics in Northern and Southern local governments in 1982 and 1992. In effect, the extent to which state aid per capita is sensitive to local government needs and resources is under examination. 


\section{CHA P TER 1: THE SIGN IF ICANCE OF}

\section{IN TERGOVER N MENTA L A ID}

\section{Statement of the Problem}

How sensitive is state intergovernmental aid, on a per capita basis, to levels of needs and resources within local governments. To what extent are state aid figures, per capita, positively correlated with measures of need? Conversely, to what extent are state aid figures, per capita, redistributional in character? In other words, to what extent are state aid figures per capita negatively correlated with measures of available resources? In effect, this study questions the methods, or decision-making systems, states use when distributing aid to local governments. The significance of this analysis lies in the circumstances surrounding it. Research on determinants of aid allocation suggests numerous factors comprising the socioeconomic status, or overall well being, of an area may go overlooked when allocating state aid to local governments (Merget 1981, Copeland and Meier 1984, Ebel 1991, Stein and Hamm 1994). If redistribution efforts to local governments with higher levels of need and lower levels of resources are not particularly strong, then areas most in need of aid remain disadvantaged.

\section{Quality of Life}

The overall quality of life within communities, an issue surrounding social policy, is an essential consideration faced by local government officials and citizens alike. Local governments are constantly challenged to maintain adequate levels of economic growth, fiscal health and public service delivery, while sustaining a sound quality of life within their areas. Czerwinski (2000) writes that even though problem areas can be categorized in basically the same manner, each community faces somewhat unique challenges. Surrounding this problem, however, is the tendency for some local officials to measure community health simply through tax receipts, the value of property and the strength of payroll. Flower (1997) notes that doing so overlooks the quality of life within a community and the degree to which residents are healthy and satisfied. 
Reeder (1996) writes that federal block grants were designed to aid socioeconomic needs of needy areas. The increased need for social services and the declining job market, low incomes, lacking tax bases, poor financial management, declining populations, geographic isolation and overall poor demographic characteristics of some localities brought increased attention in the form of intergovernmental aid. Hasler (1986), Feder and Hadley (1986) and Schneider and Logan (1986) all note targeting aid began with the idea that the allocation of greater and more targeted resources to localities in need can have a beneficial effect on those residents in need. If methods of aid allocation, and determinants used within them, do not account for such factors, local governments in need may become further damaged.

\section{Declining Aid and Issues of Aid Allocation}

The situation of declining aid may provide important context to the measures able to be tested in this study. The rationale behind this consideration stems partly from the research of Merget (1981) and Ebel (1991) on determinants and methods of aid allocation to local governments. Overall, these authors suggest numerous factors comprising the socioeconomic status, or overall well-being, of an area are overlooked when deciding how to allocate aid. In the process, those areas experiencing more severe degrees of need continue to lack needed aid, resources and attention. At the same time however, aid that is being allocated to local governments is declining. In other words, while there may be a lack of effective targeting to those areas with the greatest degree of need, there is also a decreasing amount of available aid to local governments.

Additionally, Johnson (1985) lends support to the idea that aid allocation becomes better informed when taking into account issues of declining aid. Johnson's analysis aimed to measure local government dependence during 1976 to1977 through use of four measures: federal and state aid as a percentage of total local revenue, federal aid as a percentage of total local revenue, federal and state intergovernmental revenues per capita, and federal-only intergovernmental revenues per capita. All four measures of dependence were negatively correlated with high growth and high income. In effect, low growth and low-income areas were more dependent on intergovernmental revenues for their needs. 
The underlying point, then, is large scale cuts in aid have the potential to harm localities dependent on social services, and those experiencing economic and population declines. At the same time however, Merget (1981), Copeland and Meier (1984), Ebel (1991) and Stein and Hamm (1994) note that population tends to be a prime determinant in aid allocation to local governments. This conflicts with the idea that areas with low growth and declining populations are more dependent on intergovernmental revenues.

\section{Issues Informing Intergovernmental Aid Allocation}

Due to the limitations of this study, certain issues that inform intergovernmental aid allocation will not be measured. These considerations may be best dealt with through a separate analysis. However, new federalism, local government officials' responses to declining intergovernmental aid and the post-Reagan administrations may give needed context to this study.

New federalism. Federalism is broadly defined as the categorization or restructuring of numerous federal programs, funded by intergovernmental aid, into a few. Conlan (1998), Liebschutz and Taddiken (1986) and Nathan and Doolittle (1985) agree that the new federalism of the Reagan administration was a drive to return many federally funded responsibilities, especially social service programs, to state and local governments. The domestic policies within new federalism called for the reduction, or elimination, of both state and federal funding for many social services and their management, as well as decreased funding to state and local governments. This policy direction resulted in a $\$ 35.2$ billion reduction in 1981 domestic program spending; a \$5 billion reduction in income security programs; the stiffening of eligibility requirements for Medicaid, food stamps, AFDC and child nutrition programs; the consolidation of seventy-seven programs into nine; and the termination of sixty-two programs including the Comprehensive Employment Training Act (CETA). Plus, seventy seven block grants were consolidated into nine under the Omnibus Budget Reconciliation Act of 1981. This shifted the responsibility of funding social services from the state to the local level. 
Eliminating inefficiencies within the federal government, then, meant having to end numerous federal programs to state and local governments. Conlan (1998) writes that goals of the Reagan administration tended to conflict with those of needy, dependent groups and the ability of federal aid to reach those most in need through domestic policies. Cole, Taebel and Hissong (1990) note the most documented consequence of new federalism, specifically within cities, is the reduction of federal aid from 13.6 percent of total revenue in 1980 to 8 percent in 1986. Regardless of region, size or economic condition, cities in general began to receive significantly smaller proportions of federal aid than in 1980 .

Responses to cuts in aid. Second, the responses of local government officials to cuts in intergovernmental aid may prove insightful to the allocation process. Morgan and Hirlinger (1993) note this may prove especially important due to the lack of research in assessing the impacts of decreases in intergovernmental aid on the most dependent locations, and the ways in which these areas have responded to reductions.

Cole and Taebel (1984) note it was widely assumed local officials would be forced to compensate for the loss of federal and state funds by reducing or removing public services, laying off local employees, raising taxes or relying more on user fees and charges. Service operating grants and employment programs, which tend to be viewed by local officials as the easiest to cut, experienced some of the greatest reductions in aid. The removal of public service employment programs accounted for about half of grant reductions. Nathan and Doolittle (1985) note that Aid to Families With Dependent Children (AFDC), Medicaid and the food stamp program, community action agency and community development block grants, and health and education block grants experienced large reductions in funding.

In short, some of the most harmed individuals were the poorest. Replacement levels for these public services were consistently low (Nathan and Doolittle 1985). Local officials tended to consider these needs as less of an immediate concern to the overall well being of localities. Many state and local governments did not feel obligated to continue funding programs perceived as federal. On the other hand, capital programs such as federal 
highway, airport and mass transit systems viewed with more political importance received increases in federal spending during the same time period.

Local governments themselves were not greatly harmed by many of the reductions in federal aid, nor even those reductions of the 1981-1982 Reagan administration budget. Peterson (1986) suggests difficult financial conditions were weathered, at least in great part, due to the detachable nature of many federally assisted programs. Programs most harmed by federal reductions were consistently those most separate from city functions and those which did not have much, if any, political influence or support. Conversely, wastewater treatment, general revenue sharing and mass transit survived without reductions. This corresponds with Cole and Taebel (1984), as cited in Peterson (1986), when finding cuts in aid during the Reagan administration coincide with political attitudes.

Overall, the degree of replacement, or the willingness of state and local governments to give additional funding to services, reflects the willingness to maintain government activities. However, Nathan and Doolittle (1984) note the community service block grant was the only block grant not to receive replacement funding from state governments. Community service agencies, legal aid, low-income housing assistance and temporary public employees were targeted for cuts in funding. Reductions in aid tended to be passed on to individual programs, not the city budgets or the taxpayers. Many social services, then, tended to be viewed by local officials as only marginal when compared to other service responsibilities. This claim is reinforced by numerous case studies conducted by the Urban Institute, as well as by case studies completed by Nathan and Doolittle (1984), Cole, Taebel and Hissong (1990) and Peterson (1986) on impacts felt by state and local governments in response to reductions in funding for the social services under the Reagan administration. Findings from these studies support the claim that service populations, or aid recipients, are most harmed by cuts in aid.

The post-Reagan administrations. Third, Conlan (1998) notes that between 1990 and 1994 six significant mandates were formed requiring state and local governments to contribute billions of dollars. By 1994, these actions, in conjunction with already existing intergovernmental regulations of the 1960s and 1970s, helped bring federal mandate 
reform, and the fiscal burdens mandates tend to carry, to the forefront local government concerns.

Conlan (1998) writes that while President Bush (1989-1993) expressed desire to channel aid to state and local governments through block grants, the 1991 State of the Union address stands in contradiction. The proposal suggested that the community development block grant, and some social service, low-income energy assistance and education block grants should, at best, receive reduced funding. While this plan was not carried out due mainly to anticipated declines in funds, it may nonetheless prove telling in regards to the nature of aid allocation.

The $104^{\text {th }}$ Congress, falling under the Clinton administration, was also marked with the desire to decrease aid to the social services. Titled the Contract with America, which began in 1994, this plan included the consolidation of 349 programs, totaling $\$ 217$ billion, into ten block grants. Conlan (1998) and King (1999) note that this pressured social service programs to compete for scarce federal funds. Some supporters of spending cuts in the social services responded by stating they did not want to harm citizens or beneficiaries dependent on government support, but they were compelled by policy to do so. In the end, however, Congress cut domestic spending by a smaller amount than proposed. While the early $104^{\text {th }}$ Congress aimed to consolidate over 300 federal programs into eight block grants, amounting to $\$ 125$ billion, twelve new block grants were finally passed and 200 small programs and agencies terminated.

Similarly, Beckman (1995) highlights the Personal Responsibility Act (PRA) of 1996 within the Contract with America of the Clinton administration. The rationale of the PRA is reducing or eliminating financial assistance to the poor will encourage a greater degree of responsibility. While the first version was rejected, King (1999) and Posner and Wrightson (1996) cite that the House of Representatives initially approved the PRA and agreed to cut $\$ 66$ billion from food and various domestic anti-poverty programs over five years; translating into an average decrease of $\$ 1,700$ per person per year for families below the poverty level (at the time, $\$ 15,000$ per year). These types of aid are generally referred to as the social safety net. The final version of the PRA was passed in August 1996; allowing food stamps to remain an entitlement program without setting an 
expenditure cap, despite the threats the program came under throughout the $104^{\text {th }}$ Congress.

King (1999) suggests decisions made surrounding the PRA tended to be based on short term political factors; not the underlying principles with which it was drafted. Social services, which tend to have weak political backing, usually experience fiscal defeat. This is especially true during times marked by competition over scarce federal funding. However, proponents of block grants cite money saved by restraining available funding for program spending and reduced federal responsibility are incentives of block grants. Conversely, opponents of block grants such as Senator John Breaux from Louisiana is quoted in King $(1999,362)$ stating:

"Block grants are like taking all the problems that we have with the welfare problem and putting them in a box, then wrapping it all up, tying a bow around it, and then mailing that box of problems to the States, saying: Here, it is yours. It is a block grant. It is a block grant of problems with less money to help solve those problems. That, I think, is not a solution."

Again, this analysis will not measure these four issues surrounding, or informing, aid allocation. However, the context provided by these issues may have important implications to measures capable of being tested. In general, research on determinants of aid allocation suggests numerous factors comprising the socioeconomic status, or overall well being, of an area may go overlooked when allocating state aid to local governments. In effect, it is possible that local governments experiencing more severe degrees of need, specifically in regards to the social services, continue to lack needed aid, resources and attention. 


\section{CHA P T ER 2:R EVIEW OF LITERA T URE}

\section{Background of Intergovernmental Aid}

Block grants. Posner and Wrightson (1996) note that although the term block grant was not yet in use, the Hoover Commission in 1949 suggested consolidated grants across broad social functions and needs would help reduce perceived inefficiencies in government. Block grants, then, share a common theme in that they are supposed to offer improved government operations through state involvement rather than federal.

Reeder (1996) adds that federal block grants, officially created in 1966, were designed to aid socioeconomic needs of disadvantaged areas; especially those needs of the rural poor. Rural areas were targeted, or given special attention, due to their need for increased social services, the declining job market, low incomes, lacking tax bases, poor financial management, declining populations, geographic isolation and overall poor demographic characteristics which can severely limit economic development. Intergovernmental aid, then, oftentimes plays a significant role in the quality of life of many rural areas (Dougherty, Klase and Song 1999, Steven 1995, Henderson 1991, Brown and Warner 1991, Molnar and Smith 1982).

In general however, Posner and Wrightson (1996) cite the potential for block grants to harm states and communities. Governors surveyed by these researchers in 1981 and 1995 indicated they would be willing to accept cuts in federal aid and the capping of federally funded programs in exchange for more state flexibility. Historically however, cuts in funding tend to remain permanent while increased flexibility becomes reversed over time. States find themselves in need of dealing with decreased federal aid and increased requirements that may lead to less efficient, more expensive operations.

Targeting aid. Rich (1993) writes that targeting aid to those areas and citizens within the United States (U.S.) with the greatest need was a gradual development. Beginning in the early 1900s, this sentiment evolved in concert with the development of the grant-in-aid system. Hasler (1986), Feder and Hadley (1986) and Schneider and Logan (1985) agree that targeting is based on the idea that the allocation of greater resources to localities in need can have a beneficial effect on those residents in need. This is the driving 
assumption behind intergovernmental aid allocation, which is to lessen the variances, or disparities, in the abilities of states and localities to locally generate needed revenues (Downes and Pogue 1992, Stein and Hamm 1987, Copeland and Meier 1984).

Rich (1993) and Downes and Pogue (1992) agree that one of the most basic issues of any political system is the degree to which government plays a role in reducing economic inequalities; including that of equal levels of public services. However, this equalizing in the form of redistributive aid is not a simple process. Rich (1993) suggests this is due, at least in great part, to the U.S. system of federalism itself, in which actions taken by one level of government can potentially shape actions taken by another. Similarly, Karski and Barth (2000) write that resource allocation is a complicated process; one which must take into account the aims of the social service program, the target population, the amount of people in need and the type of work that must be done for the equal distribution of needed social services.

In all, Rich (1993) notes that there are three dimensions of targeting. These dimensions are the degree to which federal funds are allocated to the places most in need, the choices made at the local level on how federal funds are distributed, and the types of activities given funding. In short, federal aid passes through three tiers of use: the allocation of aid to places in need, neighborhoods in need, and finally people in need. In the process of identifying and discussing these dimensions, Rich emphasizes that too much attention has been given to decision making at the federal level. In the process, roles played by state and local governments in shaping aid distribution become overlooked. Choices made at the local level, then, can have a significant impact on which localities receive aid, and to what extent aid received is actually beneficial to those in need.

Rich (1993) highlights a point central to this analysis. Namely, different methods of aid allocation to local governments can influence the types of areas that benefit. Similarly, Hasler (1986) notes that methods of aid distribution can influence the degree to which aid received is beneficial for those residents in need. If methods of aid allocation do not take into account the increased needs for social services, lower incomes and declining job markets, lacking tax bases, declining populations and overall poor demographic characteristics some local governments demonstrate, local governments in need may 
become further damaged. Within the context of these critical issues, determinants of aid allocation take precedence as a significant issue for needy and dependent localities and their residents.

\section{Previous Research on Intergovernmental Aid}

Available literature on the study of intergovernmental aid allocation to local governments is sparse. Research is especially lacking considering the fact that aid allocation is not a new issue, and considering the importance of aid redistribution within socioeconomically disadvantaged areas. In short, determinants used to allocate funds to local governments have not been fully researched.

Rich (1993) writes that available literature on determinants of intergovernmental aid allocation has been conceptually and empirically lacking. Hasler (1986) is one of only a few studies concentrating on the targeting of aid within local governments, and the implications allocation formulas have on targeting to the poor. This work gives mention to an unpublished study, conducted in 1977 at the Urban Institute, titled "The Substate Allocation Of Title XX Funds." Hasler $(1986,28)$ notes that this study found "there were almost as many procedures for allocating resources as there are states." Focusing on allocation within the local level, Downes and Pogue $(1992,480)$ cite the "currently poor state of knowledge about...the process of local government decision making." While Hasler (1986) and Rich (1993) agree there is little available literature on intergovernmental aid allocation, Karski and Barth $(2000,46)$ cite both Hasler's and Rich's work when stating their own analysis on child welfare allocation methods "had relatively little to build on" due to "scant literature on traditional sub-state allocation." In this way, while research was lacking in 1986 and even into 1993, the situation has remained the same into 2000. Additionally, some researchers highlight that available literature may be biased because it has tended to treat aid allocation within all states and localities the same (Barnes 1993, Pelissero and Morgan 1992, Stein and Hamm 1987). 


\section{Determinants of Intergovernmental Aid Allocation}

Taken as a whole, the available literature on determinants of intergovernmental aid allocation, while lacking in regards to set methods of aid distribution, does allow for the identification of commonly used, as well as commonly overlooked, determinants. While this identification is a compilation of numerous pieces of research, it nonetheless highlights determinants that tend to be used by federal and state governments when allocating funding to the local level. Certainly, this compilation is preliminary and basic.

Population and tax rates. Stein and Hamm (1994) highlight the tendency for state aid to be received not by those localities with the greatest need, but by those with the greatest populations and highest tax burdens. Noteworthy, this study suggests population and tax rates have been common determinants used by states when finding that twentyeight states demonstrated this tendency. In 1977, 34 percent of states studied distributed inter-governmental aid to local governments based on tax rates; dropping to 31 percent in 1982. The authors attribute some credit for these targeting practices to the political unpopularity of income redistributions to the poor. Similarly, Ebel (1991), studying county spending patterns, found county governments tend to offer more financial assistance to counties with the largest populations; not necessarily those demonstrating the greatest need.

Merget (1981) found that larger U.S. cities, regardless of the type of financial assistance, tend to receive greater amounts of aid. While cities with populations greater than one million received an average of $\$ 484.98$ in intergovernmental aid per person, the smallest cities received only $\$ 134.07$ per person. Merget suggests using population as the prime determinant of public spending overlooks needy and dependent groups such as children, elderly and the impoverished who may not necessarily live in highly populated areas. Plus, using population by itself overlooks the fact that even cities with the largest populations do not conform to any clear pattern of fiscal and public needs.

Similarly, Copeland and Meier (1984) found that state population tends to be positively related to the distribution of federal grants. Only $5 \%$ of the state to state variation in federal grant funding could not be accounted for by population. Per capita income, percent of families in poverty, tax effort, unemployment rates, urbanization and 
age of infrastructure were not significant in explaining grant allocation. When these variables were included in the analysis, they had no significant impact on the explanatory power of population. The authors comment that congressional decisions have a history of being based on population.

Due to problems with multicollinearity, this study does not include population density. However, percent of individuals living in an urban area does helps account for population density.

Metropolitan Status. Rich's (1993) research on intergovernmental aid allocation suggests a link between metropolitan status and population as determinants of aid distribution. Locally managed suburban cities and urban municipalities demonstrated the greatest degree of targeting to needy residents. Rich suggests that these areas are also those with smaller and more manageable numbers of people. Conversely, targeting efforts among the federal and state levels were the least likely to benefit local residents with the greatest needs. Relating to population as a determinate of aid distribution, the prospect of targeting becomes less likely at the federal and state levels because of the greater numbers of needy recipients. The same situation is believed to be true for the number of political jurisdictions within each level of government: the greater the number of jurisdictions, the worse the record for targeting. Rich suggests this can be attributed, in great part, to the need for a large, supportive legislature. The amount of funding available for targeting to programs presents a similar situation, because it tends to be easier to target to smaller programs.

Supporting Rich's (1993) findings, Reeder (1996) and Stein and Hamm (1987) suggest rural communities suffer when forced to compete for grants against urban communities. Many rural areas do not qualify for block grant assistance due to inadequate tax bases, and therefore find themselves receiving insufficient amounts of aid.

While some research claims that rural areas have not benefited from intergovernmental aid allocation, other research states the same for urban areas. Dye and Hurley (1978) aimed to measure the responsiveness of federal and state aid to the urban needs of 243 cities found in the nation's Standard Metropolitan Statistical Areas as of 1970. 
In all cities studied, total federal aid was unrelated to every measure of need except for percent nonwhite and crime rate. In this way, federal aid was unrelated to population size, age of the population, aging infrastructure, age of the city, percent of families below the poverty level, median family income, public assistance rate, segregation and education. State aid, on the other hand, was more closely related to urban needs; specifically population size, growth and density, age of the city and segregation. However, these differences were moderate. Overall, Dye and Hurley indicate in this research, and in a brief response published in 1981, federal spending in urban areas tends to not be directed towards those cities with the greatest needs.

Poverty rate and income. There is some discrepancy as to whether poverty rate and issues of income are treated as important determinants in the allocation of aid to local governments. Rich (1993) suggests the degree to which impoverished populations are concentrated tends to be a significant factor in allocation. Rich found that suburban cities receiving the most targeted aid were also those with one or more block groups comprised of low to moderate-income persons. Thus, the extent to which local officials perceive an area to be in need has an important bearing on the amount of aid targeted. In the case of this study, a higher poverty rate translated into a greater amount of targeted aid to needy persons. However, this finding conflicts with that of Copeland and Meier (1984) in which percent of families in poverty was not a strong predictor of allocation.

Due to problems with multicollinearity, this study does not include per capita income. However, percent of individuals below the poverty level does help account for this factor.

\section{Potential Non-Determinants of Intergovernmental Aid Allocation}

Although previously mentioned, two studies draw attention to factors that tend to remain unconsidered when determining aid allocation to local governments. These studies are worth reiterating because of the types of factors in question. Keeping in mind the purpose of intergovernmental aid, which is to lessen variances in the abilities of states and localities to locally generate needed revenues (Downes and Pogue 1992, Stein and Hamm 
1987, Copeland and Meier 1984) overlooking these determinants may harm needy localities. Determinants overlooked indicate measures of need and help determine overall quality of life.

First, when Copeland and Meier (1984) found state population, more than any other factor included in their analysis, tended to be significantly and positively related to the distribution of federal grants, their study took on important implications. Namely, per capita income, percent of families in poverty, tax effort, unemployment rates, urbanization and age of infrastructure were unable to account for federal aid allocation as powerfully as population.

Second, Dye and Hurley (1978) measured the responsiveness of federal and state aid to urban needs. In all cities studied, total federal aid was unrelated to every measure of need except for percent nonwhite and crime rate. Federal aid, then, was unrelated to population size, age of the population, aging infrastructure, age of the city, percent of families below the poverty level, median family income, public assistance rate, segregation and education. While state aid was more closely related to urban needs, specifically in regards to population size, growth and density, age of the city and segregation, the difference from federal aid was only moderate. Again, these factors are central to a locality's socioeconomic health and overall quality of life.

Complimenting these two studies, Schneider and Logan (1985) found that intergovernmental aid to suburbs in the mid-1970s tended to not be targeted to lower income locations. While suburbs in general received a greater amount of intergovernmental aid through the 1970s, the largest increases went to middle-income suburbs. Reeder (1996), Yagi (1995), and Stein and Hamm $(1994,1987)$ agree that allocating aid based on factors such as income overlooks local governments with the greatest socioeconomic needs.

\section{Methods of Intergovernmental Aid Allocation}

As highlighted by Dye and Hurley (1978) and Copeland and Meier (1984), factors representing quality of life issues within the community level have tended to be overlooked by states when allocating aid. This tendency is reinforced by taking into account allocation methods, or practices, present within state redistribution. Determinants of aid within these 
methods compliment research suggesting wealth and population size are prime determinants of state aid distribution to local governments.

Hasler (1986), focusing specifically on social service programs funded by the Social Service Block Grant (formerly known as Title XX), gives needed attention to state allocation methods. Hasler first gives an overview of the three most frequently used methods of aid allocation to sub-state governments. These methods are the availability of local funds, historical allocation, and caseload statistics. Availability of local funds, while aiding jurisdictions, tends to assist only those most able to raise funds locally. More wealthy and prosperous areas tend to benefit from this method, while areas with the greatest need receive the least attention due to their inability to raise the necessary funds. Historical allocation tends to support only those areas able to develop a significant demand for a program and the resources to fund it. Areas with smaller populations, unable to meet the quota for demand, do not receive sufficient aid. Caseload statistics allocates according to the number of available cases. In this method, areas with smaller population are again left without needed assistance.

Importantly, Hasler also gives attention to three other methods of allocation rarely, if at all, used. These methods are indicators of need, demand for service, and program performance. While indicators of need may allow for better targeting of aid, this method goes unused due to its requirements. Namely, the target population and the best suiting indicators of need must be identified. Demand for service, while having the potential to better identify the extent of need for services, goes unused because it requires constantly updated data. Program performance, requiring concise program objectives for successful allocation, also remains unused. Hasler stresses that the necessities surrounding these methods, the time and money they require, contribute to their rare use.

Similarly, McCready and Rahn (1986) highlight the debate over two specific allocation methods for funding social service programs. These methods are fixed utility and fixed budget. The fixed utility method of allocation aims to meet standards for social well being, or problem alleviation, regardless of cost. The fixed budget method, on the other hand, aims to keep costs to a minimum and focuses instead on expenditures. The 
fixed budget method, a traditional approach to funding, proves inadequate because it focuses only on cost and overlooks standards for social well being and problem alleviation.

\section{Potential Political Factors in Aid Allocation}

McCready and Rahn (1986) suggest that comparing the fixed budget and fixed utility methods of aid allocation highlights the competing value preferences of local officials, agency administrators, social workers, and residents in need. Local officials may decide that certain social problems are too expensive to deal with because only marginal benefits may result from a significant amount of funding. Helping alleviate other needs with a higher value per dollar, then, is a frequent outcome. Although this analysis will be unable to test for competing value preferences, a potential determinant of aid allocation, it is important to give attention to research suggesting that political factors may account for at least some variation in aid allocation.

Copeland and Meier (1984) found that population was by far the most significant, explanatory factor in accounting for aid allocation. However, the authors note that population by itself cannot account for all of the variance in allocation. Political factors are credited and may help account for the variance that population cannot.

Relating, Yagi (1995) holds that politicians and government officials are often characterized with shortsightedness in making allocation decisions. Choices made often center on short-term policy results, regardless of the degree to which the decisions truly aid those most in need. Additionally, an information gap is present between local government officials and state and federal officials. Yagi credits this gap as contributing to the allocation of resources to areas with new, attractive projects and not those needing the money for public services or maintenance. This trend corresponds with Pelissero and Morgan $(1992,986)$ in their research on the "law of political dispersion" within federal and state funding to public schools. Meaning, local officials may broadly distribute funding to better ensure their future reelections. However, significant targeting to the poor becomes lost because they are not considered politically important. Similarly, federal and state aid to public schools was found to be influenced mainly by enrollment, and not significantly 
targeted to districts with children from impoverished families and lower per capita incomes.

Just as Pelissero and Morgan (1992) highlighted the tendency to spread benefits widely in order to ensure political support, Rich (1993) focuses on this point in research on the CDBG program. This study gives attention to the wide variation in willingness and ability of governments to target aid to the poor. Officials at federal, state and local levels alike have demonstrated the tendency to allocate funding widely; in the process not targeting aid to those with the greatest need. Targeting to those places, neighborhoods and people most in need was found to have declined over the course of the CDBG program. A more prominent federal role, however, usually meant a greater degree of targeting to the poor.

Overall, Rich (1993) found redirecting program responsibility from the federal government to the sates, such as through block grants, has not brought about a greater degree of responsiveness. Targeting attempts to small communities were less responsive and benefits varied widely under state initiatives in a majority of states. Within only a few states did targeting actually increase when allocated with state-led initiatives. CDBG funding was commonly spread well outside the ranges of those areas with the greatest need, as well as those that had previously received HUD aid. Furthermore, decisions made by local officials on the types of activities to receive funding led to a distribution of aid which exceeded the locations of individuals with low to moderate incomes. Rich suggests it is not unusual for governments to spread aid widely. Targeting varies both across and within the levels of government, while also varying according to the type of decision making system, or formula, in use. 


\section{CHA P T ER 3: RE SEARCH PROCEDURES}

\section{Data and Methods}

Data for this study are drawn from the U.S. Department of Commerce, Bureau of Labor Statistics: County Statistics. In all, 683 counties are included; 300 counties from the Northern states of Pennsylvania, New York, Michigan and Ohio, and 383 counties from the Southern states of Mississippi, Louisiana, Alabama, Arkansas, and Tennessee. Financial data for each county represent amounts from all local governments. In this way, the term local government represents county governments and any municipality, township, school district and special district within the county.

The purpose of this research is to examine the sensitivity of state intergovernmental aid per capita to measures of resources, infrastructure, social services, social problems and demographics in Northern and Southern local governments, in 1982 and 1992. In order to test these questions, ordinary least squares (OLS) multiple linear regression analysis is used to regress independent variables on state aid per capita to local governments in the North and South, in 1982 and 1992.

The dependent variable in this study is intergovernmental aid from state government, represented in per capita figures.

The independent measures for this analysis represent measures of local government resources, infrastructure, social services, social problems and demographics. Representing resources, this analysis includes property value (in natural log form), per capita total tax rate, and percent of persons with a college degree or more. Representing infrastructure, this analysis includes percent of persons living in housing built in 1949 and prior. Representing the condition of the social services, or what Posner and Wrightson (1996) terms the social safety net, this study includes percent of individuals receiving Supplemental Security Income benefits and percent of individuals receiving Social Security benefits. Percent of individuals age 65 and older was not included in this analysis because 
percent of individuals receiving Social Security generally represents the same population. Representing social problems, this analysis includes crime rate, percent of families below the poverty level and percent of unemployed individuals. Lastly, representing demographics, this study includes percent of individuals living in an urban area, percent of children aged 5 to 17 and percent of non-white individuals. Property value is represented in natural log form due to the variable's skew in its original form. Transforming it greatly improves the normality of its distribution.

\section{Variable Definitions And Building}

Definitions of variables in this analysis are gathered from the U.S. Department of Commerce, Bureau of Labor Statistics (Co-Stat 4 1992).

College plus: College Plus for 1980 and 1990 represent persons age 25 and over completing 4 years or more of college. To express these variables in per capita terms, the original values were divided by the populations for the appropriate years, then multiplied by 100 to form percentages.

Crime rate: Crime statistics for 1979 and 1989 represent the number of serious crimes known to police for that year. Serious crimes include violent crimes (murder and non-negligent manslaughter, forcible rape, robbery and aggravated assault) and property crimes (burglary, larceny-theft, and motor vehicle theft). To express this variable in per capita terms, the original values were divided by the populations for 1980 and 1990 respectively, then multiplied by 100 to form percentages.

Families below poverty level: Families in poverty during 1979 and 1989 are classified as below poverty level by comparing total income to the poverty threshold. This threshold varies according to the size of family and the age of the head of household. Poverty status is also determined for persons who are not members of a family; excluding inmates, Armed Forces members living in barracks, college students in dormitories, and unrelated persons under age 15. To express these 
variables in per capita terms, the original values were divided by the populations for 1980 and 1990 respectively, then multiplied by 100 to form percentages.

Minor: Minor for 1980 and 1990 represent children age 5 to 14, 15, 16 and 17. Age is classified as age at last birthday. To express these variables in per capita terms, the number of all children age 5 to 14,15, 16, and 17, for 1980 and 1990 respectively, were first added together. These values were divided by the populations for the appropriate years, then multiplied by 100 to form percentages.

Non-white population: Nonwhite population during 1980 and 1990 is comprised of Black, Asian and Pacific Islander, Hispanic, American Indian, Eskimo and Aleut, and Other. Race is based on a person's self-identification, and does not represent a specific scientific or biological definition. Black population includes persons who did not classify themselves as Black, but instead entered Black Puerto Rican, Haitian, Jamaican, Nigerian or West Indian. Asian and Pacific Islander includes those who indicated Japanese, Chinese, Filipino, Korean, Asian Indian, Vietnamese, Hawaiian, Guamanian and Samoan. Hispanic includes Mexican, Puerto Rican, Cuban and other Hispanic. American Indian, Eskimo and Aleut include those who did not indicate a specific race but instead reported the name of an Indian tribe. Persons of Other race include all races not given a specific category. To express these variables in per capita terms, the number of all minorities, for 1980 and 1990 respectively, were first added together. These values were divided by the populations for the appropriate years, then multiplied by 100 to form percentages.

Older housing: Older housing for 1980 and 1990 represent year-round housing built 1949 to 1940 and 1939 or earlier. A housing unit is a house, apartment, mobile home, trailer, group of rooms or single room used as a separate living space (i.e., those spaces in which occupants do not live or eat with others in the building, and those in which occupants have access to the outside through a shared hall). Year built refers to when the building was first constructed, not remodeled. To make this 
variable, number of persons living in housing built 1949 to 1940 and 1939 or earlier were first added, for 1980 and 1990 respectively. These variables were expressed in per capita terms by dividing these values by the populations for the appropriate years, then multiplying by 100 to form percentages.

Property value: Property value for 1980 and 1990, expressed in natural log terms, represents the respondent's estimate of what the house and property would sell for. Statistics are for one-family houses, on less than 10 acres, with no business on the property. This variable was transformed into natural $\log$ form due to its severe skew.

Social Security recipients: Social Security benefits recipients during 1980 and 1990, in per capita terms, represents persons age 65 and older eligible for full-retirement benefits. Persons 62 and older, eligible for reduced benefits, is included. Data also includes special-age 72 benefits, representing men age 72 before 1972 and women age 72 before 1970 who do not quality for retired worker benefits. These variables were expressed in per capita terms by dividing these values by the populations for the appropriate years, then multiplying by 100 to form percentages.

SSI recipients: Supplemental Security Income (SSI), for 1980 and 1990, in per capita terms, provides cash assistance for persons with limited income and resources who are aged (65 and older), blind or disabled (unable to take part in a gainful occupation due to medical, physical or mental handicap). Money received from SSI is that which, when combined with the person's gross income, will raise total monthly income to the Federal benefit rate. These variables were expressed in per capita terms by dividing these values by the populations for the appropriate years, then multiplying by 100 to form percentages.

State aid to local government: Intergovernmental aid from state government for 1982 and 1992, in per capita figures, represent amounts fiscal aid received from the Federal and state government. This excludes amounts received from other governments 
through sale of property, commodities and utilities. All intergovernmental revenue is treated as general revenue. Intergovernmental revenue from the state is all aid received from the state government, including aid channeled through the state level but originally from the Federal Government. To express these figures in per capita terms, values were divided by the populations for the appropriate years, then multiplied by 1000 to form percentages.

Total tax: Total tax for 1982 and 1992, per capita, represent amounts received from all government taxes. Total tax includes: (1) Property taxes based on ownership and value of property, taxes on property as a whole, real and personal, tangible or intangible. (2) Sales and gross receipts taxes based on volume or value of goods and services, gross receipts or gross income, and the use, storage, production or importation of goods. These variables were expressed in per capita terms by dividing these values by the populations for the appropriate years, then multiplying by 100 to form percentages.

Unemployed: The unemployed civilian labor force during 1979 and 1989, in per capita figures, represent civilians age 16 and over who were not at work, those with a job but not at work, and those available and looking for work during the previous four weeks. Additionally, those not working but waiting to be called back from a layoff are included. These variables were expressed in per capita terms by dividing these values by the populations for 1980 and 1990, respectively, then multiplying by 100 to form percentages.

Urban: Urban status during 1980 and 1990, in per capita figures, represents persons living in urbanized areas and places outside of urban areas with populations of 2,500 of more. Urbanized areas are defined as concentrations of 50,000 persons or more. These variables were expressed in per capita terms by dividing these values by the populations for the appropriate years, then multiplying by 100 to form percentages. 


\section{Research Aims}

This analysis is not intended to argue that state intergovernmental aid per capita should be positively related with every measure of need, or that state aid per capita should be negatively associated with all measures of resources. In other words, taking into account the numerous programs and services funded through state intergovernmental aid, it is not expected that state aid per capita will be consistently redistributed to local governments with greater signs of socioeconomic hardship. The review of literature demonstrates that this is not the case. Instead, this analysis is intended to examine the relationship of state aid per capita to measures of resources, infrastructure, social services, social problems and demographics in Northern and Southern local governments in 1982 and 1992. In effect, the extent to which state aid per capita is sensitive to local government needs is under examination.

Specifically, this study aims to test the following:

1) To what extent are state aid figures per capita correlated with measures of need within local governments? In other words, to what extent are state aid figures per capita positively correlated with percent of individuals living in older housing, percent receiving AFDC, SSI and Social Security, crime, percent below poverty and percent unemployed?

2) To what extent are state aid figures per capita redistributional in character, or negatively correlated with measure of resources? In other words, to what extent are state aid figures per capita negatively correlated with property value, total tax per capita, per capita income and percent with a college degree or more?

3) Do state aid figures per capita differ according to time-period? That is, what effects may new federalism have on the distribution of state aid per capita from 1982 to 1992 ?

4) Do state aid figures per capita differ according to region? That is, are there any significant differences in state aid distribution per capita among Northern and Southern local governments? This question tests traditional frostbelt/sunbelt characterizations. 


\section{CHAPTER 4: RESEARCH FINDINGS AND DISCUSSION}

\section{Multiple Regression Models}

This analysis contains four separate models; each testing the extent to which local government resources, infrastructure, social services, social problems and demographics results in state aid per capita. Each analysis is properly specified, or normally distributed. Standard residuals show that all means equal zero and all standard deviations approximate one.

The general model of the extent to which local governments in the North, in 1982, received state intergovernmental aid per capita is seen as:

$\hat{y}=3051.159$ (Constant) - 273.645 (Property Value: $\ln )+5.621$ (Total Tax Per Capita $)+7.556$ (Percent Old House $)+0$ (Crime Rate $)+0$ (Percent College Plus $)+$ 0 (Percent Minor) - 3.429 (Percent Non-White) + 86.981 (Percent SSI) - 771.157 (Percent Unemployed) + 0 (Percent Below Poverty) - 19.882 (Percent Social Security) +.951 (Percent Urban)

The general model of the extent to which local governments in the South, in 1982, received state intergovernmental aid per capita is seen as:

$\hat{y}=793.400$ (Constant) - 80.39 (Property Value: $\ln )+3.856$ (Total Tax Per Capita)

+ 0 (Percent Old House $)+0$ (Crime Rate) +0 (Percent College Plus $)+12.835$

$($ Percent Minor) +1.465 (Percent Non-White) +15.513 (Percent SSI) +460.42

(Percent Unemployed $)+0$ (Percent Below Poverty $)+0$ (Percent Social Security) + 0 (Percent Urban) 
The general model of the extent to which local governments in the North, in 1992, received state intergovernmental aid per capita is seen as:

$\hat{y}=2466.05$ (Constant) -273.645 (Property Value: 1n) + 4.389 (Total Tax Per Capita $)+14.431$ (Percent Old House) + 25.08 (Crime Rate) -20.887 (Percent College Plus) + 0 (Percent Minor) - 4.318 (Percent Non-White) +138.956 (Percent SSI) - 1015.691 (Percent Unemployed) + 0 (Percent Below Poverty) - 29.596 (Percent Social Security) + 0 (Percent Urban)

The general model of the extent to which local governments in the South, in 1992, received state intergovernmental aid per capita is seen as:

$\hat{y}=4362.824$ (Constant) - 401.575 (Property Value: $\ln )+1.965$ (Total Tax Per Capita) - 12.099 (Percent Old House) +0 (Crime) +0 (Percent College Plus) + 21.826 (Percent Minor) + 1.786 (Percent Non-White) + 0 (Percent SSI) - 520.981 (Percent Unemployed $)+0$ (Percent Below Poverty) + 0 (Percent Social Security) + 0 (Percent Urban)

\section{Findings}

Tables 1 through 4 show the means, standard deviations and ranges for all independent variables in each of the four models. The f statistics for these analyses show that the alternative hypotheses cannot be accepted. The independent variables in each analysis are significantly related to state aid per capita. The strength of this statement, however, differs according to time-period and region. Tables 5 through 8 present the OLS multiple regression coefficients for the four models. The independent variables in these regression analyses show that state aid per capita, as a whole and according to categories, differs according to both region and time-period. In the North in 1982, the independent variables account for $66.1 \%$ of the variance in per capita state aid, while in 1992 they account for $68.1 \%$. In the South in 1982 , the independent variables account for $48.2 \%$ of the variance in aid, while in 1992 they account for only 46.6\%. This shows that the independent variables consistently account for more variation in state aid per capita in the North than the South. 


\section{College plus}

In 1982, the effects of percent of individuals with a college degree or more, controlling for all other independent variables, is insignificant in both the North and South.

In 1992, the effects of percent of individuals with a college degree or more changed in the North. Percent with a college degree is now negatively associated with state aid per capita. For each one percent increase in college-educated individuals, there is a \$20.887 decrease in state aid. The Beta ${ }^{2}$ of .060 tells that 6 percent of the variance in state aid per capita to Northern local governments is explained by college educated individuals. In the South, percent with a college degree or more remains insignificant.

\section{Crime}

In 1982, crime rate is insignificant in both the North and South, controlling for all other independent variables.

In 1992, crime rate is positively related to state aid per capita in the North. Each one-unit increase in crime increases state aid per capita by $\$ 25.08$. The Beta ${ }^{2}$ of .027 tells that 2.7 percent of the variance in state aid per capita to Northern local governments is explained by crime rate. In the South, however, crime rate remains insignificant.

\section{Families below poverty level}

In 1982, the effect of percent of families below the poverty level on state aid per capita is not significant in the North or South, controlling for all other independent variables. This situation remains true for 1992 as well.

\section{Minors}

The effects of percent of minors in the North and South in 1982 differs regionally, controlling for all other independent variables. While percent of minors is insignificant in the North, it is positively related to state aid per capita in the South. Each one-percent increase in percent minors yields, on average, a $\$ 12.84$ increase in state aid per capita. The Beta $^{2}$ of .060 tells that 6 percent of the variance in state aid per capita to Southern local governments is explained by percent of minors. 
In 1992, this situation remains the same. While percent of minors is again insignificant in the North, it is positively related to state aid per capita in the South. Each one-percent increase in percent of minors accounts for a $\$ 21.83$ increase in state aid. The Beta $^{2}$ of .094 tells that 9.4 percent of the variance in state aid per capita to Southern local governments is explained by percent of minors, controlling for all other independent variables.

\section{Non-white population}

In 1982, the effects of percent of non-white individuals differs according to region, controlling for all other independent variables. In the North, percent non-white is negatively related to state aid per capita. Each one-percent increase in percent non-white yields a $\$ 3.43$ decrease in state aid. The Beta $^{2}$ of .023 tells that 2.3 percent of the variance in state aid per capita to Northern local governments is explained by percent non-white. In the South however, each one-percent increase in percent non-white yields a $\$ 1.47$ increase in state aid per capita. The Beta ${ }^{2}$ of .064 tells that 6.4 percent of the variance in state aid per capita is explained by percent non-white.

This situation remains the same in 1992. In the North, percent non-white is still negatively related to state aid per capita. For each one-percent increase in percent nonwhite, there is a $\$ 4.318$ decrease in aid. The Beta ${ }^{2}$ of .018 tells that 1.8 percent of the variance in state aid per capita is explained by percent non-white. In the South, each onepercent increase in percent non-white yields a $\$ 1.79$ increase in state aid per capita. The Beta $^{2}$ of .044 tells that 4.4 percent of the variance in state aid per capita to Southern local governments is explained by percent non-white, controlling for all other independent variables.

\section{Older housing}

In 1982, the effects of percent of individuals living in older housing on state aid per capita, controlling for all other independent variables, differs regionally. In the North, percent living in older housing is positively related to state aid per capita. Each onepercent increase in percent living in older housing increases state aid per capita by $\$ 7.56$. 
The Beta ${ }^{2}$ of .067 tells that 6.7 percent of the variation in aid to Northern local governments is explained by percent living in older housing. In the South however, percent living in older housing is not a significant factor.

This situation changed in 1992. Percent living in older housing is a significant factor in both the North and South, controlling for all other independent variables. However, the directions of the relationships differ. In the North, each one-percent increase in percent living in older housing yields a $\$ 14.43$ increase state aid per capita. The Beta 2 of .092 shows that 9.2 percent of the variance in state aid to Northern local governments is explained by percent living in older housing. In the South, each one percent living in older housing decreases state aid per capita by $\$ 12.10$. The Beta ${ }^{2}$ of .024 tells that 2.4 percent of the variance in per capita state aid to Southern local governments is explained by percent living in older housing.

\section{Property value (ln)}

In 1982, the effects of property value on state aid per capita, controlling for all other independent variables, is negatively in both the North and South. In the North, each onepercent increase in property value yields a $\$ 273.65$ decrease in state aid. The Beta ${ }^{2}$ of .109 tells that 10.9 percent of the variation in aid to local governments is explained by property value. In the South, each one-percent increase in property value yields a $\$ 80.39$ decrease in state aid. The Beta ${ }^{2}$ of .026 tells that 2.6 percent of the variation in state aid per capita to Southern local governments in explained by property value.

This situation remains the same in 1992. In the North, controlling for all other independent variables, each one-percent increase in property value yields a $\$ 175.96$ decrease in state aid. The Beta ${ }^{2}$ of .042 tells that 4.2 percent of the variance to Northern local governments is explained by property value. In the South, each one-percent increase in property value yields a $\$ 401.58$ decrease in aid. The Beta ${ }^{2}$ of .276 tells that property value explains 27.6 percent of the variation in state aid to Southern local governments in 1992. 


\section{Social Security recipients}

In 1982, the effects of percent of individuals receiving Social Security on state aid per capita, controlling for all other independent variables, differs regionally. In the North, percent of Social Security recipients negatively affects aid. For each one-percent increase in persons receiving Social Security, there is a $\$ 19.88$ decrease in state aid per capita. The Beta ${ }^{2}$ of .185 tells that 18.5 percent of the variance in state aid is explained by percent receiving Social Security. In the South however, percent receiving Social Security is not significant.

In 1992, this situation remains the same. In the North, each one-percent increase in individuals receiving Social Security yields a $\$ 29.60$ decrease in state aid per capita. The Beta $^{2}$ of .143 tells that 14.3 percent of the variance in aid to Northern local governments is explained by percent receiving Social Security. In the South, however, percent receiving Social Security remains insignificant.

\section{SSI recipients}

In 1982, percent of individuals receiving SSI, controlling for all other variables, has a positive relationship in both Northern and Southern local governments. In the North, for each one-percent increase in percent receiving SSI, there is a $\$ 86.98$ increase in state aid per capita. The Beta ${ }^{2}$ of .102 tells that percent receiving SSI explains 10.2 percent of the variance in aid to local governments in the North. In the South, for each one-percent increase in percent receiving SSI, there is a $\$ 15.51$ increase in aid. The Beta ${ }^{2}$ of ..064 tells that 6.4 percent of the variance in state aid per capita to Southern local governments is explained by percent receiving SSI.

In 1992, this situation changed somewhat. Percent of individuals receiving SSI is still significant and positive in the North. For each one-percent increase in percent receiving SSI, there is a $\$ 138.96$ increase in aid. The Beta ${ }^{2}$ of .099 tells that 9.9 percent of the variance in state aid per capita to Northern local governments is explained by percent receiving SSI. However, percent receiving SSI is no longer a significant factor in the South, controlling for all other independent variables. 


\section{Total tax}

In 1982, the effect of per capita total tax on state aid per capita is positive in both Northern and Southern local governments, controlling for all other independent variables. In the North, each one-percent increase in per capita total tax increases state aid by $\$ 5.62$. The Beta ${ }^{2}$ of .50 tells that per capita total tax explains 50 percent of the variance in state aid. In the South, each one-percent increase in per capita total tax increases aid by $\$ 3.86$. The Beta $^{2}$ of .112 shows that 11.2 percent of the variance in state aid to local governments in the South is explained by per capita total tax.

In 1992, this situation remained the same, controlling for all other independent variables. In the North, each one-percent increase in per capita total tax increases aid by $\$ 4.39$. The Beta ${ }^{2}$ of .442 tells that 44.2 percent of the variance in state aid per capita to local governments is explained by per capita total tax. In the South, each one-percent increase in per capita total tax increases aid by $\$ 1.97$. The Beta ${ }^{2}$ of .043 shows that 4.3 percent of the variance in aid to local governments in the South is explained by per capita total tax.

\section{Unemployed}

In 1982, the effects of percent unemployed on state aid per capita, controlling for all other independent variables, differs regionally. In the North, percent unemployed is negatively related to aid. For each one-percent increase in percent unemployed, there is a $\$ 771.16$ decrease in state aid per capita. The Beta ${ }^{2}$ of .042 tells that 4.2 percent of the variance in aid is explained by percent unemployed. In the South however, percent unemployed has a positive effect on state aid per capita. Each one-percent increase in percent unemployed yields a $\$ 460.42$ increase in state aid. The Beta ${ }^{2}$ of .018 tells that 1.8 percent of the variance in state aid per capita to Southern local governments is explained by percent unemployed.

This situation changed in 1992. For, percent unemployed in both the North and South demonstrates a significant, negative relationship with state aid per capita, controlling for all other independent variables. In the North, each one-percent increase in percent 
unemployed decreases aid by $\$ 1015.69$. The Beta ${ }^{2}$ of .024 tells that 2.4 percent of the variance in state aid per capita is explained by percent unemployed. In the South, each one-percent increase in percent unemployed decreases state aid by $\$ 520.98$. The Beta ${ }^{2}$ of .025 shows that 2.5 percent of the variance in aid is explained by percent unemployed.

\section{Urban}

In 1982, the effects of percent urban on state aid per capita, controlling for all other independent variables, differs regionally. In the North, percent urban is positively related to state aid. For each one-percent increase in percent urban, state aid increases by $\$ .95$. The Beta ${ }^{2}$ of .017 tells that 1.7 percent of the variation in state aid per capita is explained by percent urban. In the South however, percent urban is not significantly related.

In 1992, this situation changed. Controlling for all other independent variables, percent urban is no longer significantly related to state aid per capita in either the North or the South.

\section{Accounting For Multicollinearity}

Multicollinearity in regression analyses develops when two or more independent variables are highly correlated; leading to less precision in the effects of the independent variables on the dependent. The higher the correlation between independent variables, the more serious the milticollinearity (Schroeder, Sjoquist and Stephan 1986). Taking into account socioeconomic variables are naturally highly correlated, this study does show signs of multicollinearity. The degree to which it is present, however, is the important consideration. To best determine the degree of multicollinearity, the variance inflation factors (VIFs) and correlations were paid particularly close attention.

The original model for these four analyses included percent receiving AFDC, population density and per capita income. However, these three variables proved problematic; making potentially significant variables insignificant. Additionally, the VIFs and correlations for these variables showed severe signs of multicollinearity. Removing these variables improved the significance of some variables, and especially improved the VIFs and correlations. 
In the revised model however, percent below the poverty level is consistently insignificant in all models, while showing high VIFs and correlations across region and time-period. This is especially true for the South in 1982 and 1992 . The question became whether this variable is truly insignificant in explaining state aid allocation per capita, or whether its insignificance is due to multicollinearity. Due to the importance of including percent below the poverty level in the analyses, an additional step was taken to try to account for the high multicollinearity. Namely, percent receiving SSI, having the highest correlations with percent below poverty (greater than .8), was taken out of the models for Southern local governments. If percent below the poverty level had become significant after doing so, this would have meant the insignificance is due to multicollinearity. However, taking percent receiving SSI out of the models did nothing to alter the insignificance of percent below poverty. In this way, percent SSI was kept in the models, and percent below poverty level remains insignificant but included in the models.

\section{Discussion of Findings}

Again, this analysis is not intended to argue that per capita state intergovernmental aid should be positively related with every measure of need, or negatively associated with all measures of resources. In other words, due to the numerous directions that state intergovernmental aid is channeled, it is not expected that state aid per capita will be consistently redistributed to local governments with greater signs of socioeconomic hardship. The review of literature demonstrates that this is not the case. Instead, this analysis is intended to examine the relationship of state aid per capita to measures of resources, infrastructure, social services, social problems and demographics in Northern and Southern local governments in 1982 and 1992. In effect, the extent to which state aid per capita is sensitive to local government needs and resources under examination.

\section{Regression coefficients}

Tables 5 through 8 present relationships between state aid per capita and measures of local government resources, infrastructure, social services, social problems and demographics. For ease of comparison, Table 9 is a composite of Tables 5 through 8. A blank space indicates that the regression coefficients were not significantly related to state 
aid per capita. These multiple regression analyses test the extent to which local government resources, infrastructure, social services, social problems and demographics result in state aid per capita.

Despite the regional differences highlights by the regression coefficients, the $\mathrm{r}^{2}$ values do highlight an important consistency. Across time-periods, the independent variables account for a greater proportion of state aid per capita to the North than the South. Again, factors not present within this analysis may account for per capita aid in the South. Domestic policy changes and political factors not able to be controlled for in this analysis may be partly to explain.

\section{Resources}

In 1982, measures of resources in both Northern and Southern local governments demonstrated some tendency towards redistribution; channeling aid to those areas with the least amount of resources. In the North, areas with higher property values received significantly less state aid per capita, on average, controlling for all other independent variables. Areas with higher total taxes did receive more state aid per capita, but the amount is less that moderate. This situation describes the South as well, but the amount of redistribution signified by property value is less powerful.

In 1992, this situation reversed. The South now shows more efforts towards channeling state aid to areas with lower levels of resources. However, it is important to note that only property value is redistributive; leaving total tax per capita and percent of college educated individuals unfavorable in regards to channeling state aid to local governments with the lowest levels of resources.

\section{Infrastructure}

There is a distinct regional difference regarding the redistributive effects of percent

of individuals living in older housing on state aid per capita. In the North in both 1982 and 1992, percent living in older housing accounts for a slight increase in state aid per capita. While this figure for Northern local governments is less than moderate, Southern local 
governments show no signs of redistribution. In fact, percent living in older housing in Southern local governments in 1992 accounts for a decrease in state aid per capita.

\section{Social Services}

Only percent of individuals receiving SSI shows signs of redistribution of state aid per capita to local governments with the greatest needs. However, this statement is significant, or strong, only in the North in 1992. While Southern local governments in 1982 do demonstrate some efforts towards redistribution, the amount is not strong. Furthermore, percent of individuals receiving Social Security accounts for a decrease in state aid per capita in Northern local governments in 1982 and 1992, while remaining insignificant in the South in both time-periods.

\section{Social Problems}

Measures of social problems do not show strong signs of redistribution of state aid per capita to local governments with the greatest needs. The only exception is the South in 1982, in which local governments with higher levels of unemployed persons received significantly more state aid per capita, controlling for all independent variables. However, other than this exception, state aid per capita is harmed by the presence of higher numbers of unemployed; while percent of families below the poverty level and crime rate remain largely insignificant to state aid received.

\section{Demographics}

There is a distinct regional difference in regards to measures of demographics. While percent of minors accounts for a slight increase in state aid per capita to Southern local governments in both time-periods, the effect is insignificant in the North. Similarly, while percent non-white accounts for a very small increase in state aid in the South in both time-periods, the effects are negative in the North. Percent living in an urban setting is largely insignificant in both regions.

\section{Summary of aid distribution}

Table 9 summarizes the distribution of state aid per capita to Northern and Southern 
local governments in 1982 and 1992. In short, redistribution efforts to local governments with high levels of need and low levels of resources are not particularly good in either the North or South, regardless of time-period. Only property value (ln) as a measure of resources is able to account for redistribution of state aid on a per capita basis. However, even this measure is not consistent across region and time. As for infrastructure, Northern local governments have allocated greater amounts of state aid per capita, in both 1982 and 1992, to areas with higher percentages of persons living in older housing. However, these amounts are not significant. As for the social services, percent of individuals receiving SSI does show some promising redistribution efforts; accounting for more state aid per capita in the North in 1982 and 1992, and in the South in 1982. However, percent unemployed offers little favorable view of state aid redistribution; especially in the North. An already significant lack of state aid per capita according to percent unemployed in Northern local governments in 1982 decreased further in 1992.

In all, the argument can be made that efforts towards redistribution according to measures of needs and resources in Northern and Southern local governments, in 1982 and 1992, are not strong. It is important to allow for the fact that total state aid to local governments, per capita, is a measure that combines many different types and uses of aid. However, this study takes an overall look at the efforts to redistribute state aid to local governments with the greatest levels of needs and lowest levels of resources. In general, redistribution is not strong.

\section{This study, compared to previous research}

Six findings within this research agree with those of previous research. First, Stein and Hamm (1994) find that localities with the highest tax burdens tend to receive the most state aid. This study agrees, although the amount received is not particularly significant. Second, Dye and Hurley (1978) note that poverty rate has not consistently been a strong predictor of state aid. This study agrees in that across region and time percent of individuals below the poverty level is insignificant. Noteworthy though, this study disagrees with Rich's (1993) finding that cities with significant low income populations have, at times, received the most aid. Third, Dye and Hurley (1978) find that indicators of 
aged populations were not significant factors in state aid distribution. Indeed, this study finds a negative relationship between state aid per capita and percent receiving Social Security in the North in both 1982 and 1992. Noteworthy though, this study disagrees with Mullins and Rosenstraub's (1992) finding a significant and positive relationship between the proportion of the population 65 and older and expenditures towards retirees. Fourth, while Dye and Hurley (1978) did not find a significant relationship between areas with a higher proportion of minority residents and state aid received, this study agrees. Although percent non-white accounts for an increase in state aid per capita in Southern local governments in 1982 and 1992, the amounts are not strong. Fifth, Dye and Hurley (1978) find that age of city and infrastructure was only moderately related to state aid. This study agrees in that percent of individuals living in older housing, when positive, is only slightly redistributive in state aid allocation. Sixth, this study agree with Dye and Hurley's (1978) finding that education level insignificant in explaining state aid allocation.

Two findings within this research disagree with those of previous research. First, while Copeland and Meier (1984) find unemployment rate is insignificant in explaining state aid allocation, this study generally finds a prominent decrease in state aid per capita according to percent unemployed. Second, Dye and Hurley (1978) find that crime is significantly and positively related to total state aid. This study generally finds crime rate insignificant in accounting for state aid allocation per capita.

\section{Study limitations}

Again, this study is not able to measure certain issues that help inform, or give context to, state aid allocation to local governments. To recap, the first of these is the domestic policies of new federalism in which both state and federal funding for many of the social services was reduced or eliminated. Conlan (1998), Cole, Taebel and Hissong (1990), Liebschutz and Taddiken (1986) and Nathan and Doolittle (1985) give in-depth information on this shift in domestic policy which resulted in less available intergovernmental aid to those areas most in need. 
Second, the responses of local government officials to aid reductions cannot be measured in this analysis. Morgan and Hirlinger (1993), Cole and Taebel (1994) and Nathan and Doolittle (1985) agree that local officials tended to cut funding to social services in order to divert funds to other areas deemed more politically important. These areas tend to be highways, airports and mass transit systems. This demonstrates the detachable nature of many social services. Cole, Taebel and Hissong (1990), Peterson (1986), Cole and Taebel (1984) and Nathan and Doolittle (1984) agree that reductions in federal and state aid to local governments did not necessarily harm local governments themselves. Many reductions in funding tended to correspond with political attitudes. Specifically, many of the social services received less funding instead of taxes being raised to compensate for need. In short, many social services tended to be viewed by local officials as only marginal when compared to other service responsibilities.

Lastly, this study cannot measure trends found within the post-Reagan administrations. King (1999), Conlan (1998), Posner and Wrightson (1996) and Beckman (1995) agree that the mistreatment of the social services within new federalism policies of the Reagan administration continued into later administrations. In other words, many of the social services continue to struggle for needed funding in light of budget restrictions.

Comparing state aid amounts for Northern and Southern local governments in 1982 and 1992, as a whole, it is evident that factors not included in this analysis are important. First, independent variables included in these regression analyses account for more state aid per capita to Northern local governments than Southern in both 1982 and 1992. Specifically, $\mathrm{r}^{2}$ values show that the independent variables in the North in 1982 explain $66.1 \%$ of the variance in aid, and 68.1 percent of variance in 1992. In the South however, only $48.2 \%$ of the variance in 1982 and $46.6 \%$ in 1992 is explained by the independent variables.

Future study

The need for continued research into state aid allocation to local governments is strong. Corresponding with previous research, this analysis supports the claim that state spending towards local governments is, in large part, unrelated to measures of local 
government needs and resources. In other words, this research lends support to the idea that state spending in local governments is not directed towards those with the greatest needs. Additionally, this research contradicts traditional frostbelt/sunbelt characterizations. Prior to the full effects of the policy changes, Cole and Taebel (1983) found that local government officials from the Sunbelt were more in favor of new federalism's policy changes than those from the Frostbelt. While officials from the North perceived having to reduce services, make layoffs and raise property taxes in order to compensate for declining state aid, officials from the South did not foresee having to make such severe actions. This research, however, finds that Northern and Southern states tend to be unwilling, or unable, to redistribute state aid per capita to local governments with the highest levels of needs and lowest levels of resources.

In order for a more complete study on state aid allocation per capita to local governments, a future study would do well to account for the limitations that this study cannot. For example, only indirectly can this study take into account the effects of new federalism by using the 1982 and 1992 time periods; 1982 pre-dates effects of new federalism and 1992 is after the fact. While not able to be controlled for, these limitations do provide context in which this analysis takes place. Consequently, only inferences can be made on the effects new federalism, local government officials' responses to declining aid, detachable programs and the post-Reagan administrations have on state aid per capita. A study controlling for these other factors, possibly through qualitative research gathering from local government officials, may produce significantly different results. 


\section{BIBLIOGRAPHY}

Barnes, Bill. 1993. "Local Matters In Economic Policy." Nation's Cities Weekly 16 (2):

2.

Beckman, David. 1995. "Domestic and Foreign Aid Targeted: Assault On The Poor." Christian Century April 1995: 356-358.

Brown, David L., and Mildred E. Warner. 1991. "Persistent Low-Income Nonmetropolitan Areas In The United States: Some Conceptual Challenges For Policy Development.” Policy Studies Journal 19 (2): 22-41.

Cole, Richard L., Delbert A. Taebel, and Rodney V. Hissong. 1990. “America's Cities And The 1980s: The Legacy Of The Reagan Years." Journal Of Urban Affairs 12 (4): 345-360.

Cole, Richard L., Delbert A. Taebel. 1984. "State Legislators and City Officials: A Comparison Of Perceptions Of Urban Problems And New Federalism Budget Cuts." Paper prepared for the Urban Institute.

Conlan, Timothy. From New Federalism To Devolution. 1998. Washington, D.C.: Brookings Institution Press.

Copeland, Gary W., and Kenneth J. Meier. 1984. "Pass The Biscuits Pappy: Congressional Decision-Making And Federal Grants." American Politics Quarterly 12 (1): 3-20.

County Statistics File 4 (Co-Stat 4): Technical Documentation. 1992. U.S. Bureau Of Commerce, Bureau Of The Census: Washington D.C.

Czerwinski, Stanley J. 2000. “Community Development, Local Growth Issues, Federal Opportunities And Challenges." FDCH Government Account Reports: 09/06/2000.

Dougherty, Michael John, Kenneth A. Klase, and Soo Geun Song. 1999. "The Needs And Financial Problems Of Small And Rural Localities: The Case Of West Virginia." Public Budgeting \& Finance 19: 16-31. 
Downes, Thomas A., and Thomas F. Pogue. 1992. "Intergovernmental Aid To Reduce Fiscal Disparities: Problems Of Definition And Measurement." Public Finance Quarterly 20 (4): 468-482.

Dye, Thomas R., and T. Lane Hurley. 1981. "Measuring Responsiveness: A Brief Reply." Journal Of Politics 43 (1): 102-103.

Dye, Thomas R., and Thomas L. Hurley. 1978. "The Responsiveness Of Federal And State Governments To Urban Problems.” Journal Of Politics 40 (1): 196-207.

Ebel, Robert D. 1991. “A Profile Of County Finances." Intergovernmental Perspective 17: 14-17.

Feder, Judith, and Jack Hadley. 1986. “Cutbacks, Recession, And Hospitals' Care For The Urban Poor." In George E. Peterson and Carol W. Lewis (Eds.). Reagan And The Cities. 1986. Washington, D.C.: Urban Institute Press.

Flower, Joe. 1997. "Beyond Economics: Healthy Communities And Healthy Economies." National Civil Review (86) 1: 53-60.

Hasler, Bonnie Sether. 1986. "Dividing The Pie: The Allocation OF Resources To Substate Areas." New England Journal Of Human Sciences 6 (4): 28-32.

Henderson, Zorika Petic. 1991. "Rural Areas Are Endangered." Human Ecology 19 (4): 31-33.

Johnson, Michael S. (1985). "Metropolitan Dependence On Intergovernmental Aid." Social Science Quarterly 66 (1): 713 - 723.

Karski, Ruth Lawrence, and Richard P. Barth. 2000. "Models Of State Budget Allocation In Child Welfare Services." Administration In Social Work 24 (2): 45-66.

King, Ronald F. 1999. "Welfare Reform: Block Grants, Expenditure Caps, And The Paradox Of The Food Stamp Program.” Political Science Quarterly 114 (3): 359385.

Liebschutz, Sarah F., and Alan J. Taddiken. 1986. "The Effects Of Reagan Administration Budget Cuts On Human Services In Rochester, New York.” In George E. Peterson and Carol W. Lewis (Eds.). Reagan And The Cities. 1986. Washington, D.C.: Urban Institute Press. 
McCready, Douglas J., and Sheldon L. Rahn. 1986. "Funding Human Services: Fixed Utility Versus Fixed Budget." Administration In Social Work 10 (4): 23-30.

Merget, Astrid E. 1981. “The Fiscal Dependency Of American Cities." Public Budgeting \& Finance 1: 20-30.

Molnar, Joseph J. and John P. Smith. 1982. "Satisfaction With Rural Services: The Policy Preferences Of Leaders And Community Residents.” Rural Sociology 47 (3): 496511.

Morgan, David R., and Michael W. Hirlinger. 1993. "The Dependent City And Intergovernmental Aid." Urban Affairs Review 29 (2): 256-276.

Nathan, Richard P., and Fred C. Doolittle. 1985. "Federal Grants: Giving And Taking Away." Political Science Quarterly 100 (1): 53-74.

Pelissero, John P., and David R. Morgan. 1992. “Targeting Intergovernmental Aid To Local Schools: An Analysis Of Federal And State Aid." The Western Political Quarterly 45 (4): 985-999.

Peterson, George E. 1986. "Urban Policy And The Cyclical Behavior Of Cities." In George E. Peterson and Carol W. Lewis (Eds.). ․ Reagan And The Cities. 1986. Washington, D.C.: Urban Institute Press.

Posner, Paul L., and Margaret T. Wrightson. 1996. "Block Grants: A Perennial, But Unstable, Tool Of Government." Publius 26 (3): 87-108.

Reeder, Richard J. 1996. "How Would Rural Areas Fare Under Block Grants?” Issues In Agriculture And Rural Finance Agricultural Information Bulletin No. 724-03: 1-4.

Rich, Michael J. 1993. Federal Policymaking And The Poor. 1993. Princeton: Princeton University Press.

Schneider, Mark, John Logan. 1985. "Suburban Municipalities: The Changing System Of Intergovernmental Relations In The Mid-1970s. Urban Affairs Quarterly 21 (1): 87-105.

Schroeder, Larry D., David L. Sjoquist, and Paula E. Stephan. Understanding Regression Analysis: An Introductory Guide. Newbury Park: Sage Publications, 1986. 
Stein, Robert M., and Keith E. Hamm. 1987. “A Comparative Analysis Of The Targeting Capacity Of State And Federal Intergovernmental Aid Allocations.” Social Science Quarterly 68: 447-465.

Stein, Robert M., and Keith H. Hamm. 1994. "Explaining State Aid Allocations: Targeting Within Universalism.” Social Science Quarterly 75: 524-539.

Steven, Alexander. 1995. "Bringing Rural America On Board." Environmental Action 26 (4): 26-28.

Yagi, Tadashi. 1995. "Deterioration Of Public Capital And Optimal Policy Of Local And Central Government." Urban Studies 32: 123-135. 


\section{A P P E N D I X}

Table 1. Mean, S.D. and Total N of Variables for Northern States, 1982

\begin{tabular}{|l|l|l|l|}
\hline \multicolumn{1}{|c|}{ Variable Name } & \multicolumn{1}{c|}{ Mean } & \multicolumn{1}{c|}{ S.D. } & \multicolumn{1}{c|}{ Description } \\
\hline Percent College Plus & 6.78 & 2.86 & Continuous (range: $2.94 \%-23.55 \%$ ) \\
\hline Crime Below & 3.59 & 2.20 & Continuous (range: .00 - 27.88) \\
\hline $\begin{array}{l}\text { Percent } \\
\text { Poverty }\end{array}$ & 10.77 & 3.51 & Continuous (range: $4.00 \%-26.98 \%$ ) \\
\hline Percent Minor & 21.82 & 1.94 & Continuous (range: $12.89 \%-27.15 \%$ ) \\
\hline Percent Non-White & 5.77 & 8.98 & Continuous (range: .40\%-86.51\%) \\
\hline Percent Old House & 17.93 & 6.89 & Continuous (range: $5.29 \%-69.59 \%$ ) \\
\hline Property Value (ln) & 10.50 & .2437 & Continuous (range: $9.57-11.44$ ) \\
\hline $\begin{array}{l}\text { Percent Social } \\
\text { Security }\end{array}$ & 17.22 & 4.35 & Continuous (range: $7.15 \%-40.60 \%$ ) \\
\hline Percent SSI & 1.44 & .7392 & Continuous (range: .28\%-5.44\%) \\
\hline $\begin{array}{l}\text { State Aid Per Capita } \\
\text { Dependent Variable) }\end{array}$ & 379.58 & 201.18 & Continuous (range: $\$ .00-\$ 2812.51$ ) \\
\hline Total Tax Per Capita & 42.23 & 25.32 & Continuous (range: $\$ .00-\$ 358.86)$ \\
\hline Percent Unemployed & .026 & .053 & Continuous (range: .00\% - .69\%) \\
\hline Percent Urban & 40.95 & 27.44 & Continuous (range: .00\% $-100.00 \%$ ) \\
\hline
\end{tabular}

Note: Total $\mathrm{N}$ for all variables $=300$ 
Table 2. Mean, S.D. and Total N of Variables for Southern States, 1982

\begin{tabular}{|l|l|l|l|}
\hline \multicolumn{1}{|c|}{ Variable Name } & \multicolumn{1}{|c|}{ Mean } & \multicolumn{1}{c|}{ S.D. } & \multicolumn{1}{c|}{ Description } \\
\hline Percent College Plus & 5.09 & 2.03 & Continuous (range: $1.60 \%-13.89 \%$ ) \\
\hline Percent Crime & 1.98 & 1.59 & Continuous (range: $.00-9.41$ ) \\
\hline Percent Below Poverty & 21.89 & 7.87 & Continuous (range: $8.31 \%-52.71 \%$ ) \\
\hline Percent Minor & 22.93 & 2.20 & Continuous (range: $15.23 \%-30.46 \%$ ) \\
\hline Percent Non-White & 24.32 & 19.89 & Continuous (range: .62\%-86.25\%) \\
\hline Percent Old House & 7.58 & 2.00 & Continuous (range: $2.44 \%-19.61 \%$ ) \\
\hline Property Value (ln) & 10.25 & .2320 & Continuous (range: $9.67-11.16)$ \\
\hline Social Security & 18.20 & 3.88 & Continuous (range: $8.33 \%-35.86 \%$ ) \\
\hline Percent SSI & 4.54 & 1.87 & Continuous (range: $.91 \%-10.59 \%$ ) \\
\hline $\begin{array}{c}\text { State Aid Per Capita } \\
\text { (Dependent Variable) }\end{array}$ & 345.19 & 115.40 & Continuous (range: $\$ 167.10-\$ 1187.77$ ) \\
\hline Total Tax Per Capita & 17.96 & 10.02 & Continuous (range: $\$ 5.82-\$ 77.16)$ \\
\hline Percent Unemployed & .038 & .034 & Continuous (range: .00\% - .22\%) \\
\hline Percent Urban & 33.97 & 24.42 & Continuous (range: .00\% - 99.91\%) \\
\hline
\end{tabular}

Note: Total $\mathrm{N}$ for all variables $=383$ 
Table 3. Mean, S.D. and Total N of Variables for Northern States, 1992

\begin{tabular}{|c|c|c|c|}
\hline Variable Name & Mean & S.D. & Description \\
\hline Percent College Plus & 8.94 & 4.10 & Continuous (range: $3.03 \%-31.08 \%$ ) \\
\hline Percent Crime & 2.96 & 2.29 & Continuous (range: $.00-31.01$ ) \\
\hline $\begin{array}{l}\text { Percent } \quad \text { Below } \\
\text { Poverty }\end{array}$ & 12.25 & 4.69 & Continuous (range: $3.51 \%-28.14 \%$ ) \\
\hline Percent Minor & 18.80 & 1.83 & Continuous (range: $11.31 \%-25.06 \%$ ) \\
\hline Percent Non-White & 7.31 & 10.76 & Continuous (range: $.51 \%-107.73 \%$ ) \\
\hline Percent Old House & 17.66 & 7.40 & Continuous (range: $5.12 \%-80.31 \%$ ) \\
\hline Property Value $(\ln )$ & 10.96 & .4072 & Continuous (range: $9.86-13.10$ ) \\
\hline $\begin{array}{ll}\text { Percent } & \text { Social } \\
\text { Security } & \\
\end{array}$ & 18.35 & 4.48 & Continuous (range: $8.70 \%-38.80 \%$ ) \\
\hline Percent SSI & 1.64 & .7978 & Continuous (range: $.37 \%-6.59 \%$ ) \\
\hline $\begin{array}{l}\text { State Aid Per Capita } \\
\text { (Dependent Variable) }\end{array}$ & 711.02 & 350.80 & Continuous (range: $\$ .00$ - \$5229.73) \\
\hline Total Tax Per Capita & 79.41 & 53.16 & Continuous (range: $\$ .00$ - \$750.38) \\
\hline Percent Unemployed & .0232 & .0532 & Continuous (range: .00\% - .77\%) \\
\hline Percent Urban & 40.80 & 27.81 & Continuous (range: $.00 \%-100.00 \%$ ) \\
\hline
\end{tabular}

Note: Total $\mathrm{N}$ for all variables $=300$ 
Table 4. Mean, S.D. and Total N of Variables for Southern States, 1992

\begin{tabular}{|l|l|l|l|}
\hline \multicolumn{1}{|c|}{ Variable Name } & \multicolumn{1}{c|}{ Mean } & \multicolumn{1}{c|}{ S.D. } & \multicolumn{1}{c|}{ Description } \\
\hline Percent College Plus & 6.63 & 2.89 & Continuous (range: $2.36 \%-21.83 \%$ ) \\
\hline Percent Crime & 2.08 & 2.11 & Continuous (range: $.00-11.98$ ) \\
\hline Percent Below Poverty & 22.74 & 8.52 & Continuous (range: $5.71 \%-56.31 \%$ ) \\
\hline Percent Minor & 20.35 & 2.42 & Continuous (range: $14.57 \%-28.16 \%$ ) \\
\hline Percent Non-White & 24.54 & 20.14 & Continuous (range: .42\%- 86.80\%) \\
\hline Percent Old House & 7.58 & 2.21 & Continuous (range: $1.94 \%-22.00 \%$ ) \\
\hline Property Value (ln) & 10.66 & .2252 & Continuous (range: $10.10-11.78$ ) \\
\hline Percent Social Security & 19.01 & 3.93 & Continuous (range: $7.70 \%-37.03 \%$ ) \\
\hline Percent SSI & 4.32 & 1.86 & Continuous (range: .86\% - 11.10\%) \\
\hline $\begin{array}{c}\text { State Aid Per Capita } \\
\text { (Dependent Variable) }\end{array}$ & 614.48 & 172.26 & Continuous (range: $\$ 124.87-\$ 2091.35$ ) \\
\hline Total Tax Per Capita & 36.05 & 18.12 & Continuous (range: $\$ 9.61-\$ 147.01$ ) \\
\hline Percent Unemployed & .0449 & .0520 & Continuous (range: .00\% - .73\%) \\
\hline Percent Urban & 33.87 & 25.08 & Continuous (range: .00\% - 99.96\%) \\
\hline
\end{tabular}

Note: Total $\mathrm{N}$ for all variables $=383$ 


\begin{tabular}{|c|c|c|c|}
\hline Independent Variables & Coefficient Value (Slope) & Beta & Beta $^{2}$ \\
\hline Y Intercept (Constant) & $3051.16^{*}$ & $\begin{array}{ll}---- \\
---\end{array}$ & $\begin{array}{ll}---- \\
\end{array}$ \\
\hline \multicolumn{4}{|l|}{ Resources } \\
\hline Property Value & $-273.645^{*}$ & -.331 & .109 \\
\hline Total Tax Per Capita & $5.621 *$ & .707 & .50 \\
\hline Percent College Plus & ----- & ----- & ----- \\
\hline \multicolumn{4}{|l|}{ Infrastructure } \\
\hline Percent Old House & $7.556^{*}$ & .259 & .067 \\
\hline \multicolumn{4}{|l|}{ Social Services } \\
\hline Percent SSI & $86.981^{*}$ & .320 & .102 \\
\hline Percent Social Security & $-19.882 *$ & -.430 & .185 \\
\hline \multicolumn{4}{|l|}{ Social Problems } \\
\hline Crime Rate & $\begin{array}{ll}---- \\
-\cdots\end{array}$ & ----- & $\begin{array}{ll}---- \\
-\cdots\end{array}$ \\
\hline Percent Below Poverty & $\begin{array}{ll}---- \\
\end{array}$ & ----- & $\begin{array}{ll}---- \\
\end{array}$ \\
\hline Percent Unemployed & $-771.157 *$ & -.205 & .042 \\
\hline \multicolumn{4}{|l|}{ Demographics } \\
\hline Percent Minor & ----- & ----- & ----- \\
\hline Percent Non-White & $-3.429 *$ & -.153 & .023 \\
\hline Percent Urban & $.951 *$ & .130 & .017 \\
\hline
\end{tabular}

Note: $\mathrm{N}=300$

$\mathrm{r}^{2}=.661$

$* p<.05$ 


\begin{tabular}{|c|c|c|c|}
\hline Independent Variables & Coefficient Value (Slope) & Beta & Beta $^{2}$ \\
\hline Y Intercept (Constant) & 793.40 & ----- & $\begin{array}{l}---- \\
\end{array}$ \\
\hline \multicolumn{4}{|l|}{ Resources } \\
\hline Property Value $(\ln )$ & $-80.39 *$ & -.162 & .026 \\
\hline Total Tax Per Capita & $3.856^{*}$ & .335 & .112 \\
\hline Percent College Plus & $\begin{array}{ll}---- \\
\end{array}$ & $\begin{array}{ll}---- \\
\end{array}$ & $\begin{array}{ll}---- \\
\end{array}$ \\
\hline \multicolumn{4}{|l|}{ Infrastructure } \\
\hline Percent Old House & $\begin{array}{ll}---- \\
---\end{array}$ & $\begin{array}{ll}---- \\
\end{array}$ & $\begin{array}{ll}---- \\
--\end{array}$ \\
\hline \multicolumn{4}{|l|}{ Social Services } \\
\hline Percent SSI & $15.513^{*}$ & .252 & .064 \\
\hline Percent Social Security & $\begin{array}{ll}---- \\
\end{array}$ & $\begin{array}{ll}---- \\
\end{array}$ & $\begin{array}{ll}---- \\
\end{array}$ \\
\hline \multicolumn{4}{|l|}{ Social Problems } \\
\hline Crime Rate & $\begin{array}{ll}---- \\
\end{array}$ & $\begin{array}{ll}---- \\
\end{array}$ & $\begin{array}{ll}---- \\
\end{array}$ \\
\hline Percent Below Poverty & $\begin{array}{ll}----- \\
\end{array}$ & $\begin{array}{ll}---- \\
\end{array}$ & $\begin{array}{ll}---- \\
-1\end{array}$ \\
\hline Percent Unemployed & $460.42 *$ & .134 & .018 \\
\hline \multicolumn{4}{|l|}{ Demographics } \\
\hline Percent Minor & $12.835^{*}$ & .245 & .060 \\
\hline Percent Non-White & $1.465^{*}$ & .253 & .064 \\
\hline Percent Urban & $\begin{array}{ll}---- \\
\end{array}$ & $\begin{array}{ll}---- \\
\end{array}$ & $\begin{array}{ll}---- \\
\end{array}$ \\
\hline
\end{tabular}

Note: $\mathrm{N}=383$

$\mathrm{r}^{2}=.482$

$* p<.05$ 


\begin{tabular}{|c|c|c|c|}
\hline Independent Variables & Coefficient Value (Slope) & Beta & Beta $^{2}$ \\
\hline Y Intercept (Constant) & $2466.05 *$ & ----- & ----- \\
\hline \multicolumn{4}{|l|}{ Resources } \\
\hline Property Value $(\ln )$ & $-175.961^{*}$ & -.204 & .042 \\
\hline Total Tax Per Capita & $4.389 *$ & .665 & .442 \\
\hline Percent College Plus & $-20.887 *$ & -.244 & .060 \\
\hline \multicolumn{4}{|l|}{ Infrastructure } \\
\hline Percent Old House & $14.431^{*}$ & .304 & .092 \\
\hline \multicolumn{4}{|l|}{ Social Services } \\
\hline Percent SSI & $138.956^{*}$ & .316 & .099 \\
\hline Percent Social Security & $-29.596 *$ & -.378 & .143 \\
\hline \multicolumn{4}{|l|}{ Social Problems } \\
\hline Crime Rate & $25.08^{*}$ & .164 & .027 \\
\hline Percent Below Poverty & $\begin{array}{ll}---- \\
---\end{array}$ & $\begin{array}{ll}---- \\
--\end{array}$ & ----- \\
\hline Percent Unemployed & $-1015.691 *$ & -.154 & .024 \\
\hline \multicolumn{4}{|l|}{ Demographics } \\
\hline Percent Minor & ----- & ----- & ----- \\
\hline Percent Non-White & $-4.318^{*}$ & -.132 & .018 \\
\hline Percent Urban & $\begin{array}{ll}---- \\
\end{array}$ & $\begin{array}{ll}---- \\
-\end{array}$ & $\begin{array}{ll}---- \\
\end{array}$ \\
\hline
\end{tabular}

Note: $\mathrm{N}=300$

$\mathrm{r}^{2}=.681$

$* p<.05$ 


\begin{tabular}{|c|c|c|c|}
\hline Independent Variables & Coefficient Value (Slope) & Beta & Beta $^{2}$ \\
\hline Y Intercept (Constant) & $4362.82 *$ & ----- & ----- \\
\hline \multicolumn{4}{|l|}{ Resources } \\
\hline Property Value (ln) & $-401.575^{*}$ & -.525 & .276 \\
\hline Total Tax Per Capita & $1.965^{*}$ & .207 & .043 \\
\hline Percent College Plus & $\begin{array}{l}---- \\
--\end{array}$ & $\begin{array}{ll}---- \\
\end{array}$ & $\begin{array}{l}---- \\
--\end{array}$ \\
\hline \multicolumn{4}{|l|}{ Infrastructure } \\
\hline Percent Old House & $-12.099 *$ & -.156 & .024 \\
\hline \multicolumn{4}{|l|}{ Social Services } \\
\hline Percent SSI & ----- & ----- & ----- \\
\hline Percent Social Security & $\begin{array}{ll}---- \\
\end{array}$ & ----- & $\begin{array}{ll}---- \\
\end{array}$ \\
\hline \multicolumn{4}{|l|}{ Social Problems } \\
\hline Crime Rate & $\begin{array}{ll}---- \\
\end{array}$ & $\begin{array}{ll}---- \\
\end{array}$ & $\begin{array}{ll}---- \\
\end{array}$ \\
\hline Percent Below Poverty & ----- & ----- & ----- \\
\hline Percent Unemployed & $-520.981 *$ & -.157 & .025 \\
\hline \multicolumn{4}{|l|}{ Demographics } \\
\hline Percent Minor & $21.826^{*}$ & .306 & .094 \\
\hline Percent Non-White & $1.786^{*}$ & .209 & .044 \\
\hline Percent Urban & $\begin{array}{ll}---- \\
\end{array}$ & ----- & $\begin{array}{ll}---- \\
\end{array}$ \\
\hline
\end{tabular}

Note: $\mathrm{N}=383$

$\mathrm{r}^{2}=.466$

$* p<.05$ 


\begin{tabular}{|c|c|c|c|c|}
\hline \multirow{2}{*}{ Independent Variables } & \multicolumn{2}{|c|}{ North } & \multicolumn{2}{|c|}{ South } \\
\hline & 1982 & 1992 & 1982 & 1992 \\
\hline \multicolumn{5}{|l|}{ Resources } \\
\hline Property Value (ln) & -273.645 & -175.961 & -80.39 & -401.575 \\
\hline Total Tax Per Capita & 5.621 & 4.389 & 3.856 & 1.965 \\
\hline Percent College Plus & ----- & -20.887 & ---- & ---- \\
\hline \multicolumn{5}{|l|}{ Infrastructure } \\
\hline Percent Old House & 7.556 & 14.431 & ----- & -12.099 \\
\hline \multicolumn{5}{|l|}{ Social Services } \\
\hline Percent SSI & 86.981 & 138.956 & 15.513 & ---- \\
\hline Percent Social Security & -19.882 & -29.596 & ---- & ----- \\
\hline \multicolumn{5}{|l|}{ Social Problems } \\
\hline Crime Rate & ---- & 25.08 & ---- & ----- \\
\hline Percent Below Poverty & ---- & ---- & ----- & ----- \\
\hline Percent Unemployed & -771.157 & -1015.691 & 460.42 & -520.981 \\
\hline \multicolumn{5}{|l|}{ Demographics } \\
\hline Percent Minor & ----- & ----- & 12.835 & 21.826 \\
\hline Percent Non-White & -3.429 & -4.318 & 1.465 & 1.786 \\
\hline Percent Urban & .951 & ---- & ---- & ---- \\
\hline $\mathbf{r}^{2}$ & .661 & .681 & .482 & .466 \\
\hline
\end{tabular}

Note: For all values listed, $\mathrm{p}<.05$ 


\section{INDEX}

Determinants of aid:

$$
\text { AFDC, 10-11 }
$$

college education, 21, 26, 27

income, 20, 21, 22

non-white, 21, 27, 28

older housing, 21, 28, 28-29

population density, 18-19, 21, 22

poverty, 27

property value, 28,29

Social Security, 28, 30

SSI, 29, 30

tax, 18-19, 29, 31

unemployment, 21, 31-32

urban, 19-20, 21, 29, 32

Federal block grants:

history of, 9-11

purpose of, 9-11

Frostbelt/Sunbelt:

characterization of, 1

Intergovernmental aid allocation:

and detachable programs, 6

decline of, 3-8

Intergovernmental aid:

allocation of (see Inter-

governmental aid allocation) determinants of, (see

Determinants of aid)

history of, 9-11 crime, 21, 26, 34

methods of, 15-17

and new federalism, 4-5

non-determinants, 14-15

previous research into, $10-18$

political factors in, 17-18

reductions in, 9-10

targeting of, 10-11

New federalism:

and declining aid, 4-5

purpose of, 4

and Reagan administration, 6-7

Quality of life:

and block grants, 2

and aid targeting, 2-3

Socioeconomic status:

resources, 34

infrastructure, 34-35

social services, 35

social problems, 35

demographics, 35 


\author{
Adam D. Baus \\ 2094 University Drive, Lemont Furnace, PA 15456 \\ (724)439-4838adam_baus@hotmail.com
}

OBJECTIVE

Seeking a position that will utilize a thorough background in sociology, research methods and skills, data collection, analysis and interpretation.

\title{
EDUCATION
}

West Virginia University

Applied Social Research: Graduate Program

Saint Vincent College

Sociology: Undergraduate Education
QPA: 3.83

Graduation May2002

QPA: 3.82

Graduated May 2000

\section{EMPLOYMENT}

Sociology Department Employee: Research Assistant

August 2001 - Present

West Virginia University: Morgantown, WV

- Research U.S. Census data in order to update existing data sets

- Construct comparative graphs and tables

- Considerable use of Microsoft Office

Sociology Department Employee: Teaching Assistant

August 2000 - August 2001

West Virginia University: Morgantown, WV

- Instructed students and provided in-class assistance during weekly archaeology labs

- Constructed archaeological dig-site with fellow students

- Proctored exams, graded exams and papers, gave weekly make-up exams

- Organized and updated records

- Maintained regular office hours for students with questions or in need of assistance

Sociology Department Employee: Teacher's Assistant

August 1998 - May 2000

Saint Vincent College, Latrobe, PA

- Graded exams and papers; proctored make-up exams

- Organized and updated records

- Maintained regular office hours for students with questions or in need of assistance

Teacher's Assistant: Intern

May 1999 - August 1999

Fayette County Community Action Agency: Uniontown, PA

- Co-taught GED, adult learning and family development classes

- Responsible for administering tests, grading short essays and homework

- Assisted in directing students towards proper social service resources 
Computer User Consultant

August 1996 - May 1998

Saint Vincent College, Latrobe, PA

- Provided assistance to students and faculty

- Provided general maintenance and upkeep within computer labs

- Received and filed questions raised by students and faculty. Recorded steps taken to in solving problems

Service Desk and Lay-away Attendant May 1998 - August 1998, Dec.1998- Jan.1999 Ames Department Store, Connellsville, PA

- Granted refunds, processed lay-away items

- Provided customer assistance, answered incoming telephone calls and in-store inquiries

\section{SKILLS}

Computer Skills: Microsoft Office (Word, Excel, PowerPoint, Access), WordPerfect Office (WordPerfect, Quattro Pro, Paradox), Statistical Package for the Social Sciences (SPSS) (Versions 8 - 10), Internet

Human Service Skills: Interpersonal, Communication, Organizational, Problem solving, Clerical, Time management

\section{HONORS}

- Recipient two year assistantship (WVU)

- Recipient three year academic scholarship (SVC)

- Recipient four year athletic scholarship (SVC)

- SVC Dean's List (8 semesters)/Alpha Chi

- Stone \& Company scholarship (SVC)

- Graduated SVC with Highest Honors

- Academic Excellence in Sociology (SVC)

\section{ACTIVITIES}

- SVC Sociology Club / Philosophy Club

- SVC Cross Country Team

- Habitat for Humanity Volunteer

- "Adopt-a-Grandparent" coordinator 


\section{REFERENCES}

Dr. F. Carson Mencken

Chairperson/Professor: Sociology Dept.

West Virginia University

307 Knapp Hall

Morgantown, WV 26506

(304) 293-5801 (ext.3212)

Prof. Patricia Rice

Chairperson/Professor: Anthropology Dept.

West Virginia University

307 Knapp Hall

Morgantown, WV 26506

(304) 293-5801 (ext. 3213)

Dr. Phyllis Riddle

Chairperson/Professor: Sociology Dept.

Saint Vincent College

300 Fraser Purchase Road,

Latrobe, PA 15650

(724) 532-6600

Dr. Thad Coreno

Professor: Sociology Dept.

Saint Vincent College

300 Fraser Purchase Road,

Latrobe, PA 15650

(724) 532-6600

Dr. George Leiner

Professor: Philosophy Dept.

Saint Vincent College

300 Fraser Purchase Road,

Latrobe, PA 15650

(724) 532-6600 